\title{
EFFECT OF THE LOG STORAGE OF Pinus taeda L. ON THE QUALITY OF KRAFT PULP
}

\author{
Guilherme Giesel ${ }^{1}$, Martha Andreia Brand ${ }^{2 *}$, Flaviana Reis Milagres ${ }^{3}$, Renato Augusto Pereira Damasio ${ }^{3}$ \\ ${ }^{1}$ University of the State of Santa Catarina, Master's Program in Forest Engineering, Lages, Santa Catarina, Brazil - ggiesel@klabin.com.br, ${ }^{* *}$ \\ martha.brand@udesc.br* \\ ${ }^{3}$ KLABIN S.A., Otácilio Costa, Santa Catarina. Brazil - fmilagres@klabin.com.br, rdamasio@klabin.com.br
}

Received for publication: 22/04/2019 - Accepted for publication: 01/11/2019

\begin{abstract}
Resumo
Efeito da estocagem das toras de Pinus taeda L. nas propriedades da madeira e na polpa celulósica. Na produção de celulose, as toras de madeira ficam estocadas por períodos que podem variar de poucas semanas a vários meses. Durante a estocagem podem ocorrer alterações nas propriedades da madeira que afetam o processo de polpação e a qualidade da polpa. Portanto, este estudo objetivou determinar o tempo ideal de estocagem das toras, por meio da avaliação das variações ocorridas (a) nas propriedades químicas da madeira, (b) nos parâmetros do processo de polpação e (c) na qualidade da polpa de Pinus taeda. Para isto, toras de $P$. taeda foram estocadas em um pátio industrial durante 30, 60, 90, 120 e 150 dias. Na madeira recém colhida, (testemunha), e em cada período de estocagem foram analisadas as propriedades físicas e químicas da madeira, os parâmetros de cozimento, e as propriedades da polpa. As propriedades químicas da madeira variaram ao longo da estocagem, porém, somente a solubilidade em hidróxido de sódio mostrou correlação positiva e significativa com o tempo de estocagem. Na polpação, o rendimento e teor de rejeitos tiveram correlação inversamente proporcional com o tempo de estocagem, enquanto o teor de sólidos orgânicos e totais tiveram correlação positiva. Quanto à qualidade da celulose, os teores de arabinanas e a lignina solúvel não variaram ao longo da estocagem. O teor de mananas teve correlação positiva e significativa com o tempo de estocagem. Levando em consideração todas as variáveis analisadas, o tempo de estocagem das toras de P. taeda deve ser de até 30 dias.

Palavras chaves: química da madeira; processo de polpação, polpa celulósica.
\end{abstract}

\begin{abstract}
In pulp production, wood in logs is stored for periods that can range from a few weeks to several months During storage, changes in the wood properties that affect the pulping process and the quality of the pulp may occur. The objective of this study was to determine the ideal timing of wood storage in logs by evaluating the variations (a) in the chemical properties of wood (b) in the parameters of the pulping process and (c) the quality of the Pinus taeda pulp. Logs were stored in an industrial courtyard for 30, 60, 90, 120 and 150 days. In each storage period, the physical and chemical properties of the wood, the cooking parameters, and the properties of the pulp were analyzed. The chemical properties of wood varied throughout storage, but only the solubility in sodium hydroxide showed a positive and significant correlation with storage time. In pulping, the yield and tailings had an inversely proportional correlation with the storage time, while the organic and total solids content had a positive correlation. As for cellulose quality, arabinan and soluble lignin contents did not vary during storage. The mannan content had a positive and significant correlation with the storage time. Taking into account all the variables analyzed, the storage time of $P$. taeda logs should be up to 30 days.

Keywords: wood chemistry; pulping process, cellulosic pulp.
\end{abstract}

\section{INTRODUCTION}

In the pulp and paper industry, wood in logs, after being received in the factory yard, is stored for periods that can range from a few weeks to several months. The storage time depends on the local conditions. According to Manzone (2015), storing the logs in uncovered piles can be considered a good method, regardless of the forest species, the log diameter and their position in the pile.

This procedure, together with the conditions of cooking, pulp washing and the process water quality can influence in the higher or lower frequency of pitch formation. Pitch is nothing but resin buildup linked to inorganic materials and fibers and varying proportions. These substances when dispersed in water tend to be deposited on metallic surfaces in critical parts of the equipment (felts and canvas), causing problems of incrustation that can reach the leaf, where they form stains (BARBOSA et al., 2005; SARTO; SANSIGOLO, 2010).

This resin is usually a mixture of resinous acids, free and combined fatty acids, unsaponifiable compounds and non-polar, olefinic and water-insoluble components (SARTO; SANSIGOLO, 2010). Therefore, high levels of extractives are undesirable in the pulping process, which results in loss of production due to the greater number of equipment shutdowns and maintenance (BARBOSA et al., 2005).

FLORESTA, Curitiba, PR, v. 50, n. 4, p. 1844 - 1853, out/dez 2020.

Geisel, G. et.al.

ISSN eletrônico 1982-4688

DOI: $10.5380 /$ rf.v50 i4. 66338 
After harvesting, the resin content immediately begins to reduce and modify its chemical composition (BRAND et al. (2011); BRAND; MUÑIZ, 2012) due to exposure to air that affects the carbon-carbon double bonds of the extractives, giving rise to strongly oxidizing free radicals, and also the action of certain enzymes that act as catalysts for the hydrolysis of esterified components. These reactions are strongly influenced by the wood storage conditions. In the first two months of storage oxidation and transformation of the extractives occurs, increasing the wood solubility in water and ethanol-toluene (BRAND; MUÑIZ, 2012).

As the wood remains stored, in addition to chemical processes, the physical and biological ones also change the wood characteristics. Regarding biodegradation, the initial stage of wood colonization after cutting the trees is associated with a high abundance of endophytic fungi (Ascomycota), which will be replaced later by microorganisms and specialized saprotrophic insects. The Ascomycota and Deuteromycota group are known as blue-colored fungi. These fungi most often attack the sapwood of gymnosperms and are known to cause minor loss of wood quality, but affect their color (NOLL; JIRJIS, 2012).

Therefore, the storage of woody biomass is a multifactorial environment that determines the microbial community presence and activity. Even the wood decomposition studied on a laboratory scale revealed nonuniform decomposition patterns (WANG et al., 2011) and therefore, it is unlikely to establish universal patterns of decomposition in wooden logs (NOLL; JIRJIS, 2012). However, it has been proven that biodegradation studies of biomass derived from forest residues stored in piles indicated that as the wood moisture content decreased the fungi attack decreased in the same proportion, and in at most 460 days of storage low levels of deterioration occurred (BØRJA, et al., 2015).

Therefore, knowing the effects of storage on wood and on the different aspects of pulp production will certainly provide subsidies for the assessment of stock levels and log storage times adopted in the pulp and paper industry. Thus, the objective of the work was to determine the ideal wood storage time in the form of logs by evaluating the variations occurring (a) in the wood chemical properties (b) in the pulping process parameters and (c) in quality of the pulp obtained from Pinus taeda $\mathrm{L}$.

\section{MATERIAL AND METHODS}

The study was conducted in the city of Otacílio Costa, state of Santa Catarina, located at $27^{\circ} 28^{\prime} 59^{\prime \prime} \mathrm{S}$ and $50^{\circ} 07^{\prime} 19^{\prime \prime} \mathrm{W}$, under subtropical weather and altitude $884 \mathrm{~m}$, from July 2017 to December 2017. Logs 7 meters long, taken from the base of recently harvested $P$. taeda $\mathrm{L}$. trees, aged 13 years old, were transported to an industrial timber yard, where they were stored in a pile 7 meters long and 2 meters high. The pile was assembled on $7 / 12 / 2017$, when the control sample (freshly collected) was collected with subsequent collections every thirty days corresponding to $30,60,90,120$ and 150 days of storage.

During the storage period the following variables were collected: relative humidity, average ambient temperature, average wind speed and solar radiation incidence, and rainfall from an industrial meteorological station approximately $1800 \mathrm{~m}$ away from the experiment site (Table 1). The data were compiled as a sum for the rainfall in daily averages for the other climatic parameters and computed in the periods between the log collections in the piles.

Tabela 1. Dados meteorológicos do período de estocagem das toras de P. taeda.

Table 1. Meteorological data of the storage period of the logs of P. taeda

\begin{tabular}{lrrrrrr}
\hline Storage time (days) & \multicolumn{1}{c}{$\mathbf{0}$} & \multicolumn{1}{c}{$\mathbf{3 0}$} & $\mathbf{6 0}$ & $\mathbf{9 0}$ & $\mathbf{1 2 0}$ & \multicolumn{1}{c}{$\mathbf{1 5 0}$} \\
\hline Collection date & $7 / 12 / 2017$ & $8 / 9 / 2017$ & $9 / 11 / 2017$ & $10 / 10 / 2017$ & $11 / 10 / 2017$ & $12 / 10 / 2017$ \\
Average temperature $\left({ }^{\circ} \mathrm{C}\right)$ & 12.1 & 11.0 & 14.3 & 16.7 & 16.4 & 18.5 \\
Average relative humidity $(\%)$ & 93.4 & 89.5 & 92.5 & 90.0 & 90.9 & 84.1 \\
Total rainfall $(\mathrm{mm})$ & 9.6 & 66.0 & 92.0 & 81.6 & 115.6 & 87.4 \\
Average wind speed $(\mathrm{m} / \mathrm{s})$ & 0.2 & 0.3 & 0.5 & 0.5 & 0.5 & 0.6 \\
Average solar radiation $\left(\mathrm{MJ} / \mathrm{m}^{2} /\right.$ day) & 9.9 & 12.4 & 12.2 & 13.7 & 15.9 & 22.3 \\
\hline
\end{tabular}

Two logs were selected and removed from the lower region, two logs from the central region and two logs from the upper stack region at each pile. Four segments of one meter in length were removed from each log, corresponding to $0,33,66$ and $100 \%$ of the log length, with approximately $20 \mathrm{~cm}$ from the top region being discarded (Figure 1). The short logs were manually peeled and turned into chips in a laboratory chipper. The chips were homogenized and classified in a Marconi MA751 laboratory classifier, according to the SCAN-CN 40:01 standard. The fraction corresponding to the chips passing through the hole sieve with a diameter of less than 45 $\mathrm{mm}$ and through the bar sieve with $8 \mathrm{~mm}$ spacing and that were retained in the sieve with a diameter greater than $7 \mathrm{~mm}$ were taken.

FLORESTA, Curitiba, PR, v. 50, n. 4, p. 1844 - 1853, out/dez 2020.

Geisel, G. et.al.

ISSN eletrônico 1982-4688

DOI: 10.5380/rf.v50 i4. 66338 


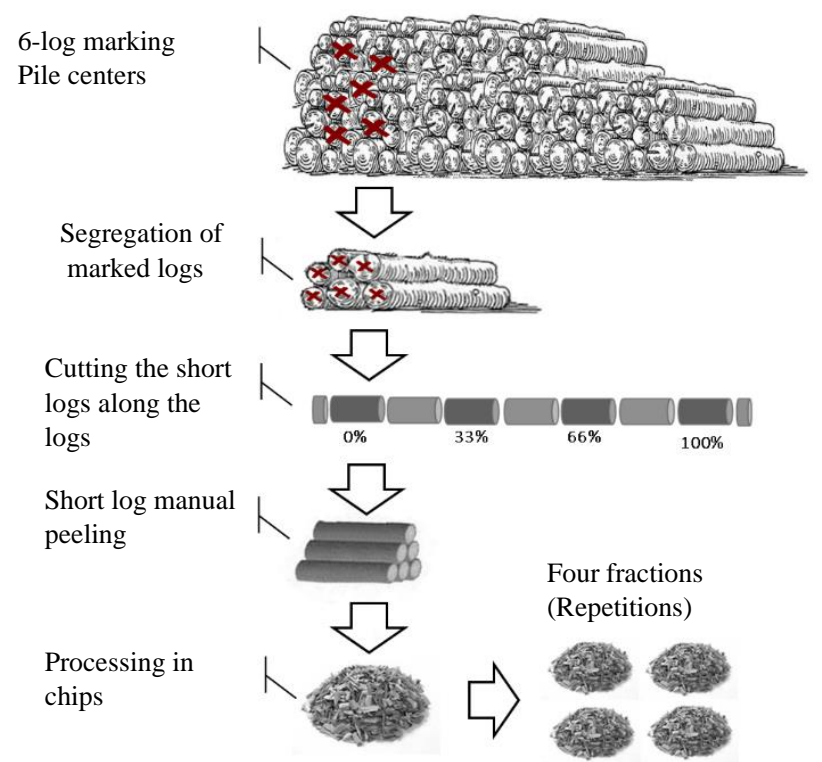

Figura 1. Diagrama da coleta e processamento das toras na pilha

Figure 1. Diagram of the collection and processing of logs on the pile

From the amount of classified and homogenized chips, four fractions of approximately $7 \mathrm{~kg}$ each were removed, stored in separate plastic bags that were identified as repetitions of each treatment and sent to the chemical analysis and cellulose pulp production in laboratory (Table 2). For the chemical analysis, the chips of each fraction were transformed into particles in a hammer-type mill and later classified in a 40 and 60 mesh sieve.

Table 2. Análises na madeira e na polpa celulósica de toras de Pinus taeda estocadas em pilhas em diferentes tempos de estocagem

Table 2. Analysis on wood and cellulosic pulp of pine logs stocked in stacks at different storage times

\begin{tabular}{|c|c|c|c|}
\hline \multicolumn{2}{|c|}{ Physical and chemical analysis in the wood } & \multicolumn{2}{|c|}{ Analysis of the cooking process and in black liquor } \\
\hline Property analyzed & Standard & Property analyzed & Standard \\
\hline Moisture content & NBR 14929 & Kappa number & ISO 302 \\
\hline Ash content & T 211 om-16 & Gross yield & Gravimetric method \\
\hline Extractives in hot water & NBR 14577 & Waste content & Gravimetric method \\
\hline Extractives & NBR 14853 & Debugged yield & Gravimetric method \\
\hline dichloromethane & & H Factor & Equation (1) \\
\hline Soluble in $\mathrm{NaOH}_{1 \%}$ & NBR 7990 & Degree of drainage & ISO 5797 \\
\hline \multirow[t]{6}{*}{ Acid insoluble lignin } & NBR 7989 & Pulp consistency & NBR 14003 \\
\hline & & Insoluble lignin and insoluble ${ }^{(1)}$ & NBR 7989 \\
\hline & & Monosaccharides $(2)$ & \\
\hline & & Total solids & T650 om - 15 \\
\hline & & Inorganic solids & Gravimetric method \\
\hline & & Residual active alkali & SCAN N2-88 \\
\hline
\end{tabular}

Legend: (1): (1) Zanuncio and Colodette (2011); (2) Wallis et al. (1996).

From each treatment ( 0 (control), 30, 60, 90, 120, 150 days of storage), four experimental cooks valid for obtaining cellulosic pulp by the Kraft process were performed. The cooking was done in a REGMED AU / 20 rotary digester equipped with four 2-liter capsules of internal volume with indirect electric heating and computerized temperature control in order to keep the temperature with an error below $0.1{ }^{\circ} \mathrm{C}$. The operational parameters used to perform the cooks were: Active Alkali Applied ( $\mathrm{NaOH}$ and $\mathrm{Na} 2 \mathrm{~S}$ expressed as $\mathrm{NaOH})$ of $12.5 \%$ on the dry weight of the chips; Sulfidity of White Liquor (28.8\%); Liquor / Wood Ratio (4: 1); Cooking temperature $\left(175{ }^{\circ} \mathrm{C}\right)$; Impregnation time $(55 \mathrm{~min}$.); Target Kappa number $(100 \pm 2)$ and H-Factor, calculated according to equation 1 proposed by Vroom (SIXTA, 2006).

$\mathrm{H}=\int_{t 0}^{t} e^{\left(43,19-\frac{16113}{\mathrm{~T}}\right)} \cdot \mathrm{dt}$

Where $\mathrm{t}$ is the time and $\mathrm{T}$ the temperature.

FLORESTA, Curitiba, PR, v. 50, n. 4, p. 1844 - 1853, out/dez 2020.

Geisel, G. et.al.

ISSN eletrônico 1982-4688

DOI: $10.5380 /$ rf.v50 i4. 66338 
At the end of each cooking, the liquor was unloaded and pressure was released to lower the temperature and interrupt the cooking, and a volume of $200 \mathrm{~mL}$ of black liquor was collected to determine the residual and total solids content. Then, the chips of each capsule were unloaded on a 300-mesh screen to perform a prewash and later defibrated in a Bauer-type laboratory refiner until a drainage degree of $13^{\circ} \mathrm{SR}$ was obtained.

The cellulose pulp was then debugged in a Somerville Regmed debugger with slits with a $0.15-\mathrm{mm}$ opening. The waste content was determined to be the mass retained in the debugger after drying in an oven at 105 $\pm 2{ }^{\circ} \mathrm{C}$ until constant weight. The fibers passing through the debugger slits were collected in a 300 mesh sieve, homogenized and weighed. Three aliquots were removed to determine consistency. The pulp was then drained and stored in a cold chamber until the execution of the subsequent steps.

The results of "gross yield", "waste content" and "debugged yield" were obtained respectively by the percentage ratio of dry pulp mass before debugging, the dry mass retained in the debugger and the debugged dry pulp mass in relation to the dry wood mass used in each cook.

The cellulose pulp was analyzed to determine the insoluble lignin content, and the filtrate was collected and enlarged to $250 \mathrm{~mL}$ and segregated to determine the soluble lignin content. This property was determined by spectrophotometry with readings at wavelengths of 215 and 280nm, as proposed by Zanuncio and Colodette (2011). The monosaccharide content was determined according to the method described by Wallis et al. (1996), and used in a Dionex ICS 5000 ion chromatography system.

In the results obtained, ANOVA was applied, the homogeneity of the variances by the Bartlett test was verified at $5 \%$ of significance and as to the normality by Shapiro-Wilk test at $5 \%$ of significance. The differences between the means were verified by the Tukey test at $5 \%$ of significance level. Minitab software version 17.2.2 was used to check and adjust the correlations between variables using the Stepwise method. In addition, to determine the linear correlation degree between the wood physical and chemical properties and the storage time, Pearson's correlation coefficient (r) was used.

\section{RESULTS}

Table 3 shows the results related to the wood chemical properties, the parameters controlled during the Kraft pulping process and the pulp properties obtained from $P$. taeda wood due to different storage times.

Tabela 3. Propriedades da madeira, qualidade do processo de polpação e propriedades da celulose de toras de $P$. taeda em diferentes tempos de estocagem

Table 3. Wood properties, quality of the pulping process and cellulose properties from $P$. taeda logs at different storage times

\begin{tabular}{|c|c|c|c|c|c|c|c|c|c|}
\hline \multicolumn{10}{|c|}{ Physical and chemical properties of $P$. taeda wood due to different storage times } \\
\hline Storage (days) & $\mathbf{0}$ & 3 & & 6 & 0 & 9 & 0 & 120 & 150 \\
\hline $\mathrm{MC}(\%)$ & $59.50 \mathrm{a}$ & 59.50 & a & 38.20 & $\mathrm{c}$ & 54.30 & $\mathrm{p}$ & $27.60 \mathrm{~d}$ & $60.00 \mathrm{a}$ \\
\hline $\mathrm{AC}(\%)$ & $0.16 \mathrm{~d}$ & 0.47 & $\mathrm{a}$ & 0.22 & $\mathrm{~cd}$ & 0.20 & $\mathrm{~cd}$ & $0.26 \mathrm{c}$ & $0.34 \mathrm{~b}$ \\
\hline HWE (\%) & $6.20 \mathrm{a}$ & 6.40 & $\mathrm{a}$ & 5.90 & $\mathrm{a}$ & 6.50 & $\mathrm{a}$ & $4.80 \mathrm{~b}$ & $4.30 \mathrm{~b}$ \\
\hline $\mathrm{DE}(\%)$ & $2.20 \mathrm{c}$ & 3.90 & $\mathrm{~b}$ & 1.90 & $\mathrm{~cd}$ & 5.10 & $\mathrm{a}$ & $1.50 \mathrm{de}$ & $1.20 \mathrm{e}$ \\
\hline $\mathrm{LT}(\%)$ & $27.70 \mathrm{~b}$ & 26.90 & $\mathrm{~cd}$ & 26.50 & $\mathrm{~d}$ & 28.90 & $\mathrm{a}$ & $27.70 \mathrm{~b}$ & $27.30 \mathrm{bc}$ \\
\hline $\mathrm{E}_{\mathrm{NaOH}}(\%)$ & $10.50 \mathrm{~d}$ & 13.70 & $\mathrm{c}$ & 13.10 & $\mathrm{~cd}$ & 15.20 & $\mathrm{~b}$ & $14.30 \mathrm{bc}$ & $17.90 \mathrm{a}$ \\
\hline \multicolumn{10}{|c|}{ Kraft pulping parameters for $P$. taeda due to storage time } \\
\hline Storage (days) & $\mathbf{0}$ & 3 & & 6 & $\mathbf{0}$ & 9 & 0 & 120 & 150 \\
\hline Kappa No. & $105.3 \mathrm{a}$ & 105.3 & a & 104.7 & $\mathrm{a}$ & 105.9 & & $104.4 \mathrm{a}$ & $105.1 \mathrm{a}$ \\
\hline GY $(\%)$ & $55.0 \mathrm{a}$ & 55.0 & a & 53.6 & $\mathrm{~b}$ & 53.6 & & $53.4 \mathrm{~b}$ & $53.0 \mathrm{~b}$ \\
\hline DY (\%) & $35.6 \mathrm{a}$ & 34.7 & $\mathrm{a}$ & 35.1 & $\mathrm{a}$ & 43.4 & $\mathrm{~b}$ & $43.0 \mathrm{~b}$ & $47.2 \mathrm{~b}$ \\
\hline WC (\%) & $19.40 \mathrm{a}$ & 20.20 & $\mathrm{a}$ & 18.50 & $\mathrm{a}$ & 10.10 & $\mathrm{~b}$ & $10.40 \mathrm{~b}$ & $5.80 \mathrm{~b}$ \\
\hline H Factor & $1025 \mathrm{c}$ & 1053 & bc & 1059 & $\mathrm{bc}$ & 1180 & $\mathrm{a}$ & 1189 a & $1111 \mathrm{~b}$ \\
\hline $\operatorname{EA~BL~}(\mathrm{g} / \mathrm{l})$ & $8.00 \mathrm{a}$ & 6.70 & $\mathrm{~cd}$ & 7.70 & $a b$ & 7.70 & $\mathrm{~b}$ & $7.10 \mathrm{bc}$ & $6.10 \mathrm{~d}$ \\
\hline BL TS (\%) & $13.70 \mathrm{~b}$ & 13.80 & $\mathrm{~b}$ & 14.30 & $\mathrm{a}$ & 14.30 & $\mathrm{a}$ & $14.30 \mathrm{a}$ & $14.30 \mathrm{a}$ \\
\hline BL OS (\%) & $9.00 \mathrm{~b}$ & 9.30 & $\mathrm{~b}$ & 9.50 & $\mathrm{a}$ & 9.50 & $\mathrm{a}$ & $9.70 \quad \mathrm{a}$ & $9.60 \mathrm{a}$ \\
\hline \multicolumn{10}{|c|}{ Chemical properties of $P$. taeda cellulose pulp due to storage time } \\
\hline Storage (days) & $\mathbf{0}$ & 3 & $\mathbf{0}$ & 6 & 0 & 9 & 0 & 120 & 150 \\
\hline Glycan $(\%)$ & $56.60 \mathrm{a}$ & 55.90 & $\mathrm{~b}$ & 56.80 & $\mathrm{a}$ & 57.00 & $\mathrm{a}$ & $56.60 \mathrm{a}$ & $56.80 \mathrm{a}$ \\
\hline Xylan (\%) & $7.58 \mathrm{a}$ & 7.33 & $\mathrm{~b}$ & 6.90 & $\mathrm{~cd}$ & 6.80 & d & $7.00 \mathrm{c}$ & $6.89 \mathrm{~cd}$ \\
\hline Mannan (\%) & $4.08 \mathrm{c}$ & 4.15 & $\mathrm{c}$ & 4.29 & $\mathrm{~b}$ & 4.38 & $a b$ & $4.42 \mathrm{a}$ & $4.39 \mathrm{ab}$ \\
\hline Arabinnan $(\%)$ & $0.84 \mathrm{a}$ & 0.86 & $\mathrm{a}$ & 0.86 & $\mathrm{a}$ & 0.83 & $\mathrm{a}$ & $0.84 \mathrm{a}$ & $0.83 \mathrm{a}$ \\
\hline Galactan $(\%)$ & $0.84 \mathrm{c}$ & 0.99 & $\mathrm{~b}$ & 1.18 & $\mathrm{a}$ & 1.00 & $\mathrm{~b}$ & $0.95 \mathrm{bc}$ & $0.98 \mathrm{~b}$ \\
\hline
\end{tabular}

FLORESTA, Curitiba, PR, v. 50, n. 4, p. 1844 - 1853, out/dez 2020.

Geisel, G. et.al.

ISSN eletrônico 1982-4688

DOI: $10.5380 /$ rf.v50 i4. 66338 


\begin{tabular}{|c|c|c|c|c|c|c|c|c|}
\hline IL (\%) & 13.94 & $14.28 \mathrm{ab}$ & 13.99 & b & 14.65 & $\mathrm{a}$ & $14.19 \mathrm{al}$ & 14.16 \\
\hline SL (\%) & 0.89 & $0.61 \mathrm{a}$ & 1.12 & $\mathrm{a}$ & 0.75 & $\mathrm{a}$ & 0.52 & 0.52 \\
\hline
\end{tabular}

Legend: $\mathrm{MC}=$ Moisture content in wet base; $\mathrm{AC}=$ Ash content $\mathrm{HWE}=$ Content of hot water soluble extractives; $\mathrm{DE}=\mathrm{Content}$ of dichloromethane soluble extractives; $\mathrm{TL}=$ Klason lignin content; $\mathrm{E}_{\mathrm{NaOH}}=$ Content of $1 \% \mathrm{NaOH}$ soluble extractives; $\mathrm{GY}=$ gross yield; $\mathrm{DY}=$ debugged yield; $\mathrm{WC}=$ waste content; $\mathrm{EA} \mathrm{BL}=$ Effective alkali in black liquor; $\mathrm{BL}$ TS= Black liquor total solids; $\mathrm{BL}$ OS= Black liquor organic solids; IL = Insoluble Lignin; SL = Soluble Lignin. Equal letters on the line indicate that there was no significant difference at a level of 5\% probability by the Tukey test.

Figure 2 shows the correlation between the value found and the estimated moisture content of P. taeda logs under storage (a) and the influence of the storage time on the P. taeda wood solubilization variations in $1 \%$ alkaline solution.

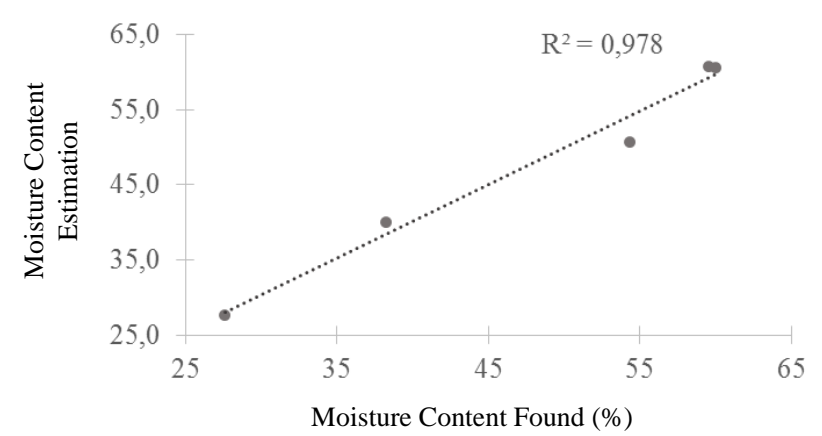

(a) Relationship between predicted and measured moisture content of $P$. taeda logs under storage based on Equation 1

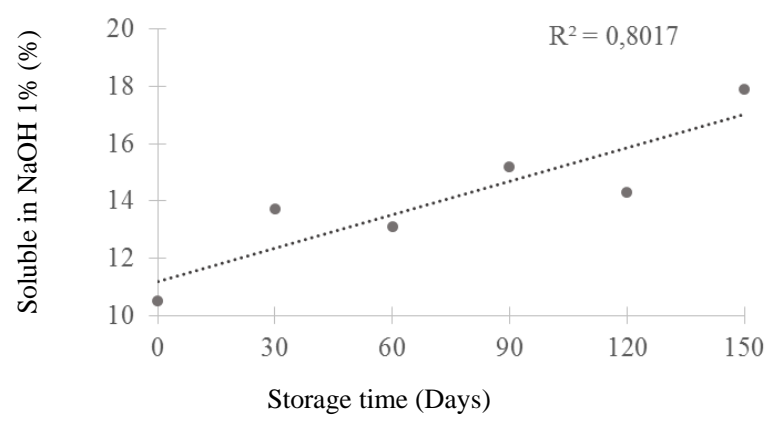

(1) Influence of storage time on the content of extractives soluble in $1 \%$ sodium hydroxide in P. taeda wood

Figura 2. Correlação entre o teor de umidade calculado e medido para madeira de $P$. taeda sob estocagem (a) e variação na solubilidade da madeira em hidróxido de sódio em função da estocagem (b).

Figure 2. Correlation between calculated and measured moisture content for P. taeda wood under storage (a) and variation in wood solubility in sodium hydroxide as a function of storage (b).

Figure 3 shows the relationship between pulp yield and $P$. taeda waste content due to storage time (a) and the correlation between the xylan content of the pulp and gross yield of wood pulp (b).

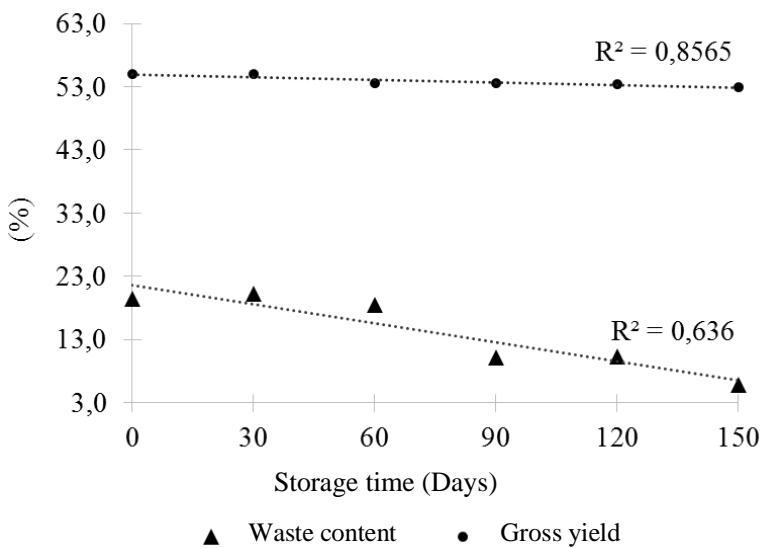

(a) Yield of P. taeda pulp due to storage time

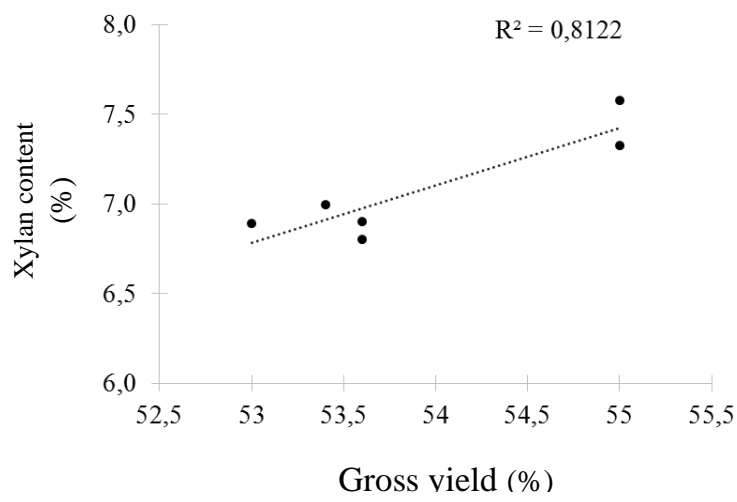

(b) Relationship between Xylan content and yield for $P$ taeda pulp

Figura 3. Variações no rendimento da polpa e no teor de rejeitos de $P$. taeda em função do tempo de estocagem (a) e relação entre o rendimento e o teor de xilanas na madeira (b).

Figure 3. Variations in P. taeda pulp yield as a function of storage time (a) and relationship between yield and xylan content in wood (b).

Figure 4 shows the variations in xylan and mannan contents (a) and in the total of polyoses (b) in P. taeda pulp due to the log storage time.

FLORESTA, Curitiba, PR, v. 50, n. 4, p. 1844 - 1853, out/dez 2020 


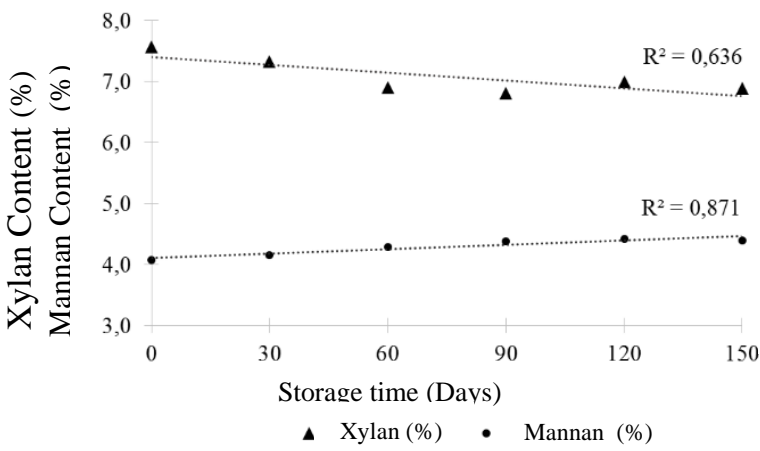

(a) Xylan and mannan content in P. taeda wood cellulose pulp due to wood storage time

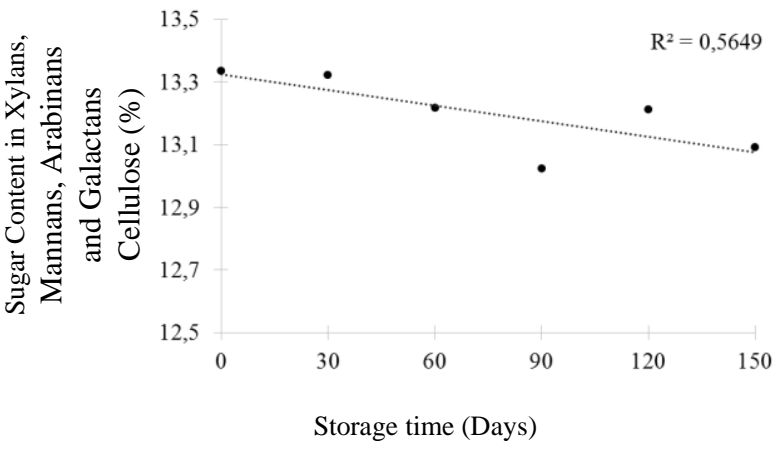

(b) Sugar Contents (xylans, mannans, arabinans and galactans) in P. taeda wood cellulose pulp due to wood storage time

Figura 4. Variações nos teores de xilanas e mananas (a) e no total de polioses (b) na polpa celulósica de $P$. taeda em função do tempo de estocagem das toras

Figure 4. Variations in xylan and mannan (a) and total polyiosis (b) contents in P. taeda pulp as a function of log storage time

\section{DISCUSSION}

\section{Variations in the physical and chemical properties of wood due to the storage time}

The moisture content remained stable in the first month of storage, with a reduction at 60 days, an increase in the period between 60 and 90 days, followed by a further reduction (120 days) and a subsequent increase until the end of the storage period. Brand et al. (2011), analyzing the influence of the storage time on the energy quality of $P$. taeda logs in different storage periods in the same study region found similar behavior. The authors recorded a constant and high moisture content in the first two months of storage with a significant reduction up to 120 days and a subsequent increase up to 180 days of storage.

In this work, the analysis of the correlation of the variables moisture content and climatic conditions using the Stepwise method demonstrated that the incidence of rain and solar radiation on the wood pile was strongly correlated with the moisture content of the stored wood. By analyzing the moisture content data of the wood and the sum of rainfall and daily average incidence of solar radiation in the time between sample collections during the periods of 30, 60, 90, 120 and 150 days, it was possible to establish the Equation 2.

$$
y=92,11+1,680_{b 1} 0,7897_{b 2}
$$

In which: $\mathrm{Y}-$ Moisture content in the wood wet base in P. taeda $\operatorname{logs}(\%) ; \mathrm{b}_{1}-$ Solar radiation $\left(\mathrm{MJ} / \mathrm{m}^{2} . \mathrm{day}\right) ; \mathrm{b}_{2}-$ Rainfall (mm).

The correlation analysis had a coefficient of determination $\left(\mathrm{R}^{2}\right)$ of 0.98 between the value found and the estimated moisture content of the logs of P. taeda under storage (Figure 2 (a)), proving the high correlation between the variables. Thus, the reduction of moisture in the logs promoted by uncovered storage in this study was more significantly influenced by precipitation and insolation than by the other climatic variables.

Routa et al. $(2015,2016)$ developed a study in Finland with the aim of establishing equations to estimate the moisture content of biomass over the storage time. The authors found that models are an easy option to estimate the moisture content of wood piles compared to sampling and measuring moisture in samples. The authors could prove that changes in Moisture are linked to climatic conditions. In the storage conditions in Finland, the climatic variables that most influenced on moisture content were rainfall and evaporation. As to Erber et al., (2014), the wind speed and air temperature govern drying, while rainfall and relative humidity contributed to rehydration of the wood. Therefore, rainfall was the climatic condition that appeared in the three studies as a determinant of the variation in moisture content during storage. The other climatic factors varied in the different study sites.

The moisture content impacts the wood behavior in the preparation of chips and in the production of the pulp. Peeling is difficult as the moisture content is reduced. When the moisture content of the wood is below the cell wall saturation point $(30 \%)$, more finer chips are produced and more small particles considered as fine are generated when it is processed into chips (KOSKINEN, 2000). Moisture levels close to the fiber saturation point were observed at 60 and 120 days of storage, and during these periods there may be problems in processing the wood for cellulose production.

Wetter chips are easier to impregnate in spite of lower liquor penetration speeds. The wetter the chip, the lower the initial speed of penetration of the cooking liquor, as water becomes a barrier to the free entry of liquor into the chip. However, the chips will have less air inside them. Therefore, even with a lower initial penetration

FLORESTA, Curitiba, PR, v. 50, n. 4, p. 1844 - 1853, out/dez 2020 
speed, it will not be affected as it can continue for a longer time, since the back pressure by the internal air is less. Additionally, wet wood favors the diffusion of cooking liquor ions. It is important to note that air is the greatest barrier to chip impregnation, not water (FOELKEL, 2009). Therefore, the moisture content of the chips must be between 45- 55\% (CAMARGO et al. 2015). Thus, higher moisture content of the wood is more suitable for the production of cellulose. Thus, considering the moisture content, the storage of logs should not exceed 30 days.

The ash content of the wood in all collections was low, varying between 0.16 and $0.47 \%$. The statistical analysis showed significant variations between the storage times, but the correlation with the storage time was not significant by Pearson's coefficient $\left(\mathrm{R}^{2}=0.12\right)$. Therefore, there was no clear trend of the storage effect on the variations observed in ash content.

As for hot water-soluble extractives, the value observed in the recently harvested wood was higher than the value reported by Brand and Muniz (2012) in P. taeda collected in May (2.26\%). During the first three months of storage, the hot water-soluble extractives remained stable, and statistically equal to the value of the wood without storage (control). In the following two months there was a significant reduction, from $23 \%$ for four months of storage and $31 \%$ for the fifth month of storage in relation to the initial value. Brand et al. (2011), on the other hand, found an increase in wood solubility in hot water after 60 days of storage. The authors stated that there were reactions of transformation and availability of extractives (oxidation, fermentation and enzymatic reactions) during the first two months of storage. The evidence for such reactions was an increase in water solubility. After four months of storage, the processed extractives were lost due to volatilization and other physical processes, resulting in a downward trend. The behavior reported by Brand et al. (2011) after 120 days was also observed in this work.

As with the ash content, and despite the variations observed in the different storage times, the solubility in hot water did not show a significant correlation at a level of 5\% probability with the storage time by Pearson's correlation coefficient. In addition, for the effective reduction of the extractive content in hot water, it would be necessary to maintain the logs under storage for periods greater than 120 days.

The dichloromethane-soluble extractives fluctuated throughout the storage period, with alternating periods of increasing and decreasing concentration, showing an effective decrease of concentration in relation to the initial content only after 120 days of storage. This indicates that the process of making these compounds available is surpassed by the decomposition and leaching process only after 120 days of storage. Period after which a $32 \%$ reduction is seen in relation to the newly-harvested wood. The reduction in the content of extractives after 120 days of storage was also reported by Brand and Muniz (2012), who attributed such reduction to the processes of chemical and enzymatic degradation of availability, leaching and evaporation of these compounds. This nonlinear behavior of the extractive content in relation to the storage time also did not correlate with the environmental variables studied $(\mathrm{P}>005)$ or with the storage time by Pearson's coefficient.

Considering the set of extractives, which form deposits called pitches and are harmful to the pulping and paper production process (BARBOSA et al., 2005; SARTO; SANSIGOLO, 2010), the storage time necessary for the elimination of these wood extractives must be at least 120 days. However, in this condition the moisture content of the wood will be close to the fiber saturation point, which is detrimental to the wood preparation and pulping process, in addition to a significant reduction in pulping yield. Therefore, the use of storage to reduce the extractives is only effective for long periods of storage of logs.

The content of soluble in 1\% Sodium Hydroxide, according to the NBR 7990 (ABNT, 2010) standard, indicates the level of degradation of the wood or cellulose pulp. This degradation is characterized by the solubilization of low molecular weight carbohydrates, including polyoses and degraded cellulose. The wood solubility of $1 \%$ alkaline were higher as the storage time increased, presenting by regression analysis $\left(\mathrm{R}^{2}\right)$ close to 0.80 (Figure $3(\mathrm{~b})$ ), and a significant Pearson correlation coefficient $\left(\mathrm{R}^{2}=0.90\right)$ with the storage time, confirming that the wood solubility in sodium hydroxide was the wood chemical property that showed the best correlation with the storage time. This confirms that there was a significant chemical change $(\mathrm{P}<0.05)$ in the carbohydrate structure during the storage period, but without a direct relation with the lignin contents in each storage period.

After 150 days of storage, an increase of $70 \%$ was seen in relation to the contents in the newly-harvested wood. The solubilization of carbohydrates in alkaline solution leads to a decrease in the cellulose pulp yield, since these compounds will also be solubilized in the alkaline conditions of the pulping process. This was confirmed by the behavior of the income results (Figure 3 (a)).

The content of insoluble lignin found in the newly-harvested wood of $27.7 \%$ was slightly higher than the value of $26.18 \%$ for P. taeda with 21 years of age, obtained by Vivian et al. (2015). This difference is due to the age difference of the wood analyzed in both studies. Despite the variations in the lignin content values between the storage times, demonstrated by the mean test, there was no significant influence of the storage time on this wood component $\left(\mathrm{R}^{2}=0.18\right)$. However, the participation of lignin in the wood composition can be changed after long periods of storage by the decomposition of polysaccharides, which in this case affect the mass ratio between lignin and the remaining polysaccharides and increasing its participation in the wood composition.

FLORESTA, Curitiba, PR, v. 50, n. 4, p. 1844 - 1853, out/dez 2020.

Geisel, G. et.al.

ISSN eletrônico 1982-4688

DOI: $10.5380 /$ rf.v50 i4. 66338 
Regarding the moisture content and chemical composition of the wood, the ideal storage time for improving the wood quality for cellulose production varied between the properties analyzed. For moisture content, storage can be of 30,90 or 150 days. For the significant reduction of pitch-forming extractives, long storage periods of at least 120 to 150 days would be necessary. The lowest levels of lignin and solubility in sodium hydroxide were obtained after 30 and 60 days of storage. Thus, the wood properties alone cannot be considered to define the ideal storage time for the wood. In this context, it is also necessary to analyze the pulping parameters and the quality of the pulp obtained from the wood at different storage times of the log.

\section{Variations in the parameters of $P$. taeda Kraft pulp production process due to the storage time}

The yield showed a strong correlation with the storage time (Figure 3 (a)) by regression analysis and significant Pearson's correlation coefficient $\left(\mathrm{R}^{2}=-0.93\right)$. As the storage time advanced the yield dropped. The reduction seen in yield was $1.4 \%$ after 60 days and $2.0 \%$ after 150 days. Although at different time scales, the reduction in yield over the storage time was reported by Koskinen (2000), who saw a $0.5 \%$ reduction for Pinus after the wood in logs remained stocked for three summers in southern Finland. The author also reinforces that this reduction in yield led to an increased consumption of wood per ton of unbleached cellulose of 10 to $15 \%$.

The xylan content in the pulp showed a statistically significant correlation with yield $(\mathrm{P}<0.05)$ (Figure 3 (b)). This indicates that the content of these carbohydrates, which are more resistant to pulping, was reduced by the action of storage, thus contributing to the increase in loss of carbohydrates in pulping and consequent reduction in yield. Delignification reactions in pulping have low selectivity. Carbohydrates are attacked as soon as they come into contact with the pulping reagents still in the impregnation phase. However, due to the high crystallinity and degree of polymerization of cellulose, the most significant losses are of polyoses, in which the speed of the reactions still depends on its type. Xylans are more stable and resistant than glycomannans, for example (ALEN et al., 2011).

No significant statistical correlations were found $(\mathrm{P}>0.05)$ between the yield and the chemical properties of the wood. However, the wood $1 \%$ sodium hydroxide solubility results increased as the storage advanced (Figure 2 (b)). This confirms that an increasing number of polysaccharides is dissolved in the alkaline conditions of pulping. As the storage time advances, the dissolution of these compounds reduces the yield of the pulp obtained. Both factors contribute to reduced yield as storage times increase.

The waste content decreased as the storage time increased (Figure 3 (b)), showing a statistically significant correlation with the storage time $\left(\mathrm{R}^{2}=-0.93\right)$. Considering that the cooking temperature was constant, the increased energy supplied was due to the increase in cooking time and this led to a greater uniformity of pulping, reducing the content of waste. To ensure uniformity of reactions during pulping, it is essential that the fibers receive an adequate amount of chemicals and energy. The non-uniformity in these items can increase the content of waste formed by uncooked fibers. The waste content is related to chips or fragments that have not been cooked well, thus remaining at the end of cooking.

The energy consumption represented by the $\mathrm{H}$ factor measurement increased as the storage time advanced up to 120 days of storage. By 150 days there was a significant reduction in energy consumption. However, the $\mathrm{H}$ factor did not show a statistically significant correlation with any other variable analyzed in this study $(\mathrm{P}>0.05)$. Significant changes in alkali consumption were observed in this period by measuring the Residual Alkali in black liquor, in addition to reduced extractives and increased solubility in sodium hydroxide. This reinforces the hypothesis that after 150 days of storage chemical reactions were less energetic than in previous periods, thus consuming more alkali and less energy.

The total solids content in black liquor increased as the storage time advanced, showing a strong and significant correlation with this $\left(\mathrm{R}^{2}=0.84\right)$. This confirms the yield behavior over the storage time. As a larger amount of material is dissolved in the cooking liquor (increase in the total solids content), there is a reduction in the amount of material present in the cellulose pulp (reduction of yield), and these two variables are inversely proportional. The content of organic solids in black liquor had the same behavior as the total solids, having a significant correlation with the storage time $\left(\mathrm{R}^{2}=0.90\right)$.

Pulping parameters had the highest number of variables with significant correlation with storage time. The variables were: yield, waste content, total solids and organic solids in black liquor. But just like the wood chemical properties, the ideal storage time was different for each variable. For the yield, total and organic solids content in black liquor, the storage time should be at most 30 days. For the H Factor it can be 30 or 60 days; for the waste content it can be 90 days, and for the effective alkali in black liquor it can be 30 or 150 days.

Therefore, evaluating both the wood properties and the process parameters, the ideal storage time for the logs to improve the wood quality and the production process should be 30 days. However, the analysis of quality of the pulp obtained in the process must be allied to this evaluation.

FLORESTA, Curitiba, PR, v. 50, n. 4, p. 1844 - 1853, out/dez 2020.

Geisel, G. et.al.

ISSN eletrônico 1982-4688

DOI: $10.5380 /$ rf.v50 i4. 66338 


\section{Variation in the Kraft pulp quality due to the storage time of $P$. taeda logs}

The levels of arabinan and soluble lignin did not show significant variations over the storage time, either by test of means or by Pearson's correlation coefficient. The other monosaccharides and the insoluble lignin content varied during the storage period. However, only the mannan content had a significant Pearson's correlation coefficient with the storage time $\left(\mathrm{R}^{2}=0.93\right)$, as well as by regression analysis (Figure $\left.4(\mathrm{a})\right)$. When assessing the effect of storage on the sum of sugars making up the polyoses (xylan, mannan, arabinan and galactan), a gradual and continuous reduction in the sugar content can be seen over the time of storage (Figure 4 (b)), although this sum does not show significant correlation $(\mathrm{P}=0.09)$ and $\left(\mathrm{R}^{2} 0.56\right)$ with the storage time by regression.

As for other wood properties and process parameters, the ideal storage time varies for each property evaluated on cellulose. However, considering the sum of monosaccharides, the wood properties and the pulping process parameters, the ideal storage time for obtaining the highest quality cellulose would be 30 days.

\section{CONCLUSIONS}

- As for the wood physical and chemical properties, only the solubility of the wood in diluted alkaline solution was significantly affected by the storage time.

- So that the wood does not lose quality for the production of cellulose, considering the properties of moisture content and solubility in sodium hydroxide, the storage time should be up to 30 days. Considering the hot water- and dichloromethane-soluble extractives, the storage time should be longer than 120 days for the significant loss of the extractives that contribute to pitch formation.

- As for the pulping process parameters, the yield, waste content and total and organic solids in black liquor were affected by the storage time of the wood in logs.

- As for the quality of cellulose, the mannan content increased while the xylan content decreased as the storage time progressed. However, only the mannan content was significantly affected by the storage time.

- $\quad$ The ideal storage time of $P$. taeda logs for improving the quality of wood for cellulose production varied for all wood properties, process parameters and cellulose pulp properties analyzed.

- Taking into account the variables analyzed together, related to the physical and chemical properties of the wood, the process parameters and the quality of the pulp obtained, the storage time of $P$. taeda logs should be up to 30 days. A time longer than this contributes to the decrease of cellulose pulp quality obtained by the Kraft process.

\section{BIBLIOGRAPHIC REFERENCES}

ASSOCIAÇÃO BRASILEIRA DE NORMAS TÉCNICAS. NBR 7990: Madeira: determinação do material solúvel em hidróxido de sódio a 1\%. Rio de Janeiro, 2010.

ALEN, R.; ANDERSSON, R.; ANNERGREEN, G.; BERG, C. G.; CHIRAT, C.; VAN DAM; J., ... GUSTAFSSON, J. Chemical Pulping Part 1, Fibre Chemistry and Technology. Helsinki: Paper Engineers' Association/Paperi ja Puu Oy, 2011.

BARBOSA, L. C. A.; MALTHA, C. R. A.; CRUZ, M. P. Composição química de extrativos lipofílicos e polares de madeira de Eucalyptus grandis. Revista Ciência \& Engenharia. Viçosa, v. 15, n. 2, p. 13-20, 2005.

BRAND, M. A.; DE MUÑIZ, G. I. B.; QUIRINO, W. F.; BRITO, J. O. Storage as a tool to improve wood fuel quality. Biomass and Bioenergy, [s.1.], v. 35, n. 7, p. 2581-2588, 2011.

BRAND, M.A.; MUÑIZ, G.I.B. Influência da época de colheita e da estocagem na composição química da biomassa florestal. Floresta e Ambiente, Rio de Janeiro, v. 19, n. 1, p. 66-78, 2012.

BØRJA, I.; ALFREDSEN, G.; FILBAKK, T.; FOSSDAL, C.G. DNA quantification of basidiomycetous fungi during storage of logging residues. PeerJ, v. 3, p. 1-15, 2015.

CAMARGO, S. K. D. C. A., DA SILVA, T. J., \& DE MOURA COSTA, D. Influência da dimensão e qualidade dos cavacos na polpação. Revista Eletrônica em Gestão, Educação e Tecnologia Ambiental, v. 19, n. 3, p. 813820, 2015.

ERBER, G.; ROUTA, J.; KOLSTROM, M.; KANZIAN, C.; SIKANEN, L.; STAMPFER, K. Comparing two different approaches in modeling small diameter energy wood drying in logwood piles. Croatian Journal of Forest Engineering, [s.1.], v. 35, n. 1, p. 15-22, 2014. 
FOELKEL, C. E. B. O processo de impregnação dos cavacos de madeira de eucalipto pelo licor Kraft de cozimento. Porto Alegre: Eucaliptus Online Book, 2009.. $\quad$ Disponível em <http://www.eucalyptus.com.br/eucaliptos/PT15_ImpregnacaoCavacos.pdf> Acesso em: 14/10/2019.

KOSKINEN, K. Wood handling applications. Chemical Pulping, [s.1.], v. 6, p. 331-491, 2000.

MANZONE, M. Energy and moisture losses during poplar and black locust logwood storage. Fuel Processing Technology, [s.1.], v. 138, p. 194-201, 2015.

NOLL, M.; JIRJIS, R. Microbial communities in large-scale wood piles and their effects on wood quality and the environment. Applied microbiology and biotechnology, v. 95, n. 3, p. 551-563, 2012.

ROUTA, J.; KOLSTRÖM, M.; RUOTSALAINEN, J.; SIKANEN, L. Validation of prediction models for estimating the moisture content of logging residues during storage. Biomass and bioenergy, [s.1.], v. 94, p. 8593, 2016.

ROUTA, J.; KOLSTRÖM, M.; RUOTSALAINEN, J.; SIKANEN, L. Validation of prediction models for estimating the moisture content of small diameter stem wood. Croatian Journal of Forest Engineering, [s.1.], v. 36, n. 2, p. 283-291, 2015.

SARTO, C.; SANSIGOLO, C. A. Cinética da remoção dos extrativos da madeira de Eucalyptus grandis durante polpação Kraft. Acta Scientiarum. Technology, v. 32, n. 3, p. 227-235, 2010.

SIXTA, H. (Ed.). Handbook of pulp. Weinheim, Germany: Wiley-vch, 2006.

TECHNICAL ASSOCIATION OF PULP AND PAPER INDUSTRY. TAPPI: T 650 om-15: Solids content of black liquor. Atlanta, Ga. 2015.

VIVIAN, M. A.; SEGURA, T. E. S.; BONFATTI JÚNIOR, E. A.; SARTO, C.; SCHMIDT, F.; JÚNIOR, S.; ... FARDIM, P. Qualidade das madeiras de Pinus taeda e Pinus sylvestris para a produção de polpa celulósica kraft. Scientia Forestalis, Piracicaba, v. 43, n. 105, p. 183-191, 2015.

WALLIS, A. F. A.; WEARNER, R. H; WRIGHT, P. J. Chemical analysis of polysaccharides in plantation eucalypt woods and pulps. Appita Journal, [s.1.], v.49, n. 4, p. 258-262, 1996.

WANG, X.; PADGETT, J.M.; DE LA CRUZ, F.B.; BARLAZ, M.A. Wood biodegradation in laboratory-scale landfills. Environ Sci Technol 45:6864-6871, 2011.

ZANUNCIO, A.J.V.; COLODETTE, J.L. Teores de lignina e ácidos urônicos na madeira e polpa celulósica de eucalipto. Revista Árvore, Lavras, v. 35, n. 2, p. 341-347, 2011. 